\title{
$\mathrm{H}_{2} \mathrm{O}_{2}$ 로 유발된 산화적 스트레스에 대한 브로콜리 (Brassica oleracea var. italica) 잎 분획물의 $\mathrm{PC12}$ cell 보호 효과
}

\author{
박선경 · 진동은 · 박창현 · 승태완 · 최성길 · 허호진* \\ 경상대학교 응용생명과학부, 농업생명과학연구원
}

\section{PC12 Cell Protective Effects of Broccoli (Brassica oleracea var. italica) Leaf Fraction against $\mathrm{H}_{2} \mathrm{O}_{2}$-induced Oxidative Stress}

\author{
Seon Kyeong Park, Dong Eun Jin, Chang Hyeon Park, Tae Wan Seung, Sung-Gil Choi, and Ho Jin Heo* \\ Division of Applied Life Science, Institute of Agriculture and Life Science, Gyeongsang National University
}

\begin{abstract}
To examine the physiological effects of broccoli (Brassica oleracea var. italica) leaf, the bioavailable compounds in broccoli leaf extract, and its in vitro neuroprotective effects against $\mathrm{H}_{2} \mathrm{O}_{2}$-induced oxidative stress were examined in this study. The chloroform fraction of broccoli leaf extract had the highest total phenolic content of all the fraction than others, and the highest 2,2"-azino-bis(3-ethylbenzothiazoline-6-sulfonic acid) diammonium salt (ABTS) radical-scavenging activity and malondialdehyde (MDA) inhibitory effect. Intracellular reactive oxygen species (ROS) accumulation resulting in $\mathrm{H}_{2} \mathrm{O}_{2}$ treated in PC12 cells was significantly lower when the chloroform fraction was present in the medium compared to that in PC12 cells treated with $\mathrm{H}_{2} \mathrm{O}_{2}$ alone. In a cell viability assay performed using 3-(4,5-dimethylthiazol-2-yl)-2,5diphenyltetrazolium bromide (MTT), the chloroform fraction showed protective effects against $\mathrm{H}_{2} \mathrm{O}_{2}$-induced neurotoxicity and inhibited lactate dehydrogenase (LDH) release into the medium. High-performance liquid chromatography (HPLC) analysis showed that ferulic acid was the predominant phenolic compound in chloroform fraction of broccoli leaf.
\end{abstract}

Keywords: broccoli, Brassica oleracea var. italica, PC12 cell, ferulic acid

\section{서 론}

지나치게 서구화된 식문화 및 식습관, 환경오염, 영양소의 과 다섭취, 흡연 및 음주 등의 다양한 요인에 의해 생성되는 활성산 소는 불안정하고 산화력이 높아 생체물질과 쉽게 반응하기 때문 에 인체 내에서 제거되지 못하면 산화적 스트레스(oxidative stress) 를 유발하게 된다(1-2). 산소는 지구상에서 가장 많은 원소로서 호기성 생물은 이렇게 풍부한 산소를 전자수용체로 하는 호흡을 통해 에너지를 획득한다. 그러나 이와 같이 생명유지에 절대적으 로 필요한 산소이지만 안정한 분자 상태인 기저삼중항산소 $\left({ }^{3} \mathrm{O}_{2}\right)$ 가 체내 효소계, 환원대사, 화학약품, 공해물질, 그리고 광화학반 응 등의 각종 물리적화학적 요인 등에 의해 superoxide radical $\left(\mathrm{O}_{2}\right)$, hydroxyl radical (HO), hydrogen peroxide $\left(\mathrm{H}_{2} \mathrm{O}_{2}\right)$ 및 일중 항산소 $\left({ }^{1} \mathrm{O}_{2}\right)$ 와 같은 반응성이 매우 큰 활성산소(reactive oxygen species; ROS)로 전환되면 생체에 치명적인 산소-유도성 독성을 일으키는 양면성을 지니고 있다(3). 우리 몸에서 발생하는 질환 중에 $90 \%$ 가 ROS와 관련이 있다고 알려져 있으며, 관련된 대표 적인 질환으로 암, 동맥 경화, 당뇨병, 그리고 심혈과 질환 등이

*Corresponding author: Ho Jin Heo, Division of Applied Life Science, Institute of Agriculture and Life Science, Gyeongsang National University, Jinju, Gyeongnam 660-701, Korea

Tel: 82-55-772-1907

Fax: 82-55-772-1909

E-mail: hjher@gnu.ac.kr

Received April 3, 2014; revised May 23, 2014;

accepted May 26, 2014
있다. 특히 신경세포는 구조적 특성상 불포화 지방산 및 구성 지 방산의 함유량이 상대적으로 높아 산화적 스트레스에 매우 취약 한 것으로 알려져 있으며, ROS의 과다 생성은 신경세포 내 산 화적 스트레스 수준의 증가를 유발하고 이는 DNA, RNA, enzymes, protein oxidation 및 lipid oxidation 등을 증가시킴으로써 신경세포의 기능장애 및 세포막 유동성의 붕괴를 초래하여 necrosis 및 apoptosis를 일으키게 된다. 이러한 산화적 스트레스에 의해 뇌졸중, 알츠하이머병(Alzheimer's disease, AD) 및 파스킨병(Parkinson's disease; PD) 등과 같은 퇴행성 뇌신경질환(neurodegenerative disease)이 유발되는 것으로 보고되고 있다 $(4,5)$. 이와 같은 생물학적 반응으로 생성된 free radical 등을 제거시켜 생체를 보 호하는 생리적 항산화 효소로는 superoxide dismutase (SOD), catalase, glutathione-peroxide (GSH-px) 및 glutathione $S$-transferase (GST) 등이 있으며, 천연생물자원에 함유된 저분자 물질로서의 free radical scavenger 역할을 하는 phenolic 화합물은 tocopherol, $\beta$-carotene, ascorbic acid 및 glutathione 등이 알려져 있다(6). 자연 에 존재하는 천연 항산화제는 과채류 등에 다량 존재하며, 이러 한 소재로 인하여 다양한 질병의 위험이 감소하는 것으로 보고 되고 있다(7). 결국 생물학적인 안전성이 입증된 다양한 식품 자 원을 포함한 천연 생물자원으로부터 보다 안정적이고 생리적 효 과가 뛰어나 관련 질환 특히 퇴행성 뇌신경 질환에 대한 예방 및 개선 효과를 나타낼 수 있는 천연 소재 발굴 및 산업화에 대한 연구가 절실히 요구되고 있는 실정이다(4).

브로콜리(broccoli, Brassica oleracea var. italica)는 십자화과에 속하는 채소로서 '모란채'라고도 하며 꽃봉오리와 줄기를 식용으 로 하는 것으로 양배추의 일종이다(8). 브로콜리는 영양학적으로 
도 중요한 작물로 전세계적으로 재배 및 식용되고 있으며, 뛰어 난 항산화 작용을 가진 dithiolethione, isothiocyanate와 같은 organosulfuric compound, $\beta$-carotene, rutin, ascorbic acid, selenium, quercetin, glutathione 등이 다량 함유되어 있는 것으로 알려지고 있다. 현재의 관련 연구는 수용성 식이섬유에 의한 혈중 콜레스 테롤 감소와 암 예방 및 돌연변이 억제 등의 생리활성 효과, 브 로콜리의 항암성분인 sulforaphane의 함량 및 조리 가공에 따른 sulforaphane의 함량변화, 브로콜리 잎 즙에 함유되어 있는 무기 질과 비타민 $\mathrm{C}$ 의 함량 분석, 그리고 브로콜리의 항산화성과 항 균성 효과 등이 보고되어 있다(9-11). 이러한 생리학적인 효능으 로 인해 브로콜리에 대한 소비자의 수요가 증가하고 있지만, 브 로콜리에서 꽃봉오리 부위만 식용으로 활용되고 있으며 그 외의 식용자원으로 활용 가능한 잎과 줄기 부분은 $70 \%$ 이상이 버려 지고 있는 실정이다 $(12,13)$. 따라서 본 연구에서는 천연 기능성 소재로 활용될 수 있지만, 대부분 불가식부의 형태로 폐기되고 있는 브로콜리의 잎 부분을 활용하여 in vitro 항산화 활성과 $\mathrm{H}_{2} \mathrm{O}_{2}$ 로 유도된 산화적 스트레스에 대한 $\mathrm{PC} 12$ 신경세포 보호효과를 밝혀 고부가가치 산업 소재로서의 활용 가능성을 알아보고자 한다.

\section{재료 및 방법}

\section{재료}

본 실험에 사용된 시료는 경기도 여주군에서 수확된 브로콜리 (Brassica oleracea var. italica) 잎 (품종: Grace)을 구입하여 사용 하였으며, $30^{\circ} \mathrm{C}$ dry oven에서 건조시켜 분쇄한 후, 냉장보관 $\left(4^{\circ} \mathrm{C}\right)$ 하면서 사용하였다. Folin-Ciocalteu's phenol reagent, gallic acid, 2,2'-azino-bis(3-ethylbenzthiazoline-6-sulfonic-acid) (ABTS), potassium ferricyanide, trichloroacetic acid, 2',7'-dichlor-ofluorescein diacetate (DCF-DA), $\mathrm{H}_{2} \mathrm{O}_{2}, 3$-(4,5-dimethylthiazol-2-yl)-2,5-diphenyl tetra-zolium bromide (MTT) assay kit, 그리고 lactate dehydrogenase (LDH) assay kit은 Sigma-Aldrich Chemical Co. (St. Louis, MO, USA) 제품을 구입하였다. 신경세포배양을 위해 필요 한 RPMI 1640 medium과 fetal bovine serum은 Gibco BRL Co. (Grand Island, NY, USA)에서 구입하였으며, penicillin, streptomycin, sodium bicarbonate와 HEPES 및 나머지 시약은 Sigma-Aldrich Chemical Co. 제품을 구입하여 사용하였다. 그 외 사용된 용 매 및 시약은 모두 일급 이상의 등급을 사용하였다.

\section{추출물의 제조}

브로콜리 잎 $48 \mathrm{~g}$ 에 $95 \%$ ethanol $2.4 \mathrm{~L}$ 을 첨가하여 환류 냉각 하에 2시간 동안 추출하였으며, 이 추출액을 No. 2 여과지(Whatman, Kent, UK)로 여과하여 진공농축기 $(\mathrm{N}-\mathrm{N}$ series, EYELA Co.,Tokyo, Japan)로 농축하였다. 그 후 이 추출물을 극성 차이를 이용하여 분획하였다. 브로콜리 잎 ethanol 추출물에 $n$-hexane과 distilled water을 $1: 1$ 비율로 분액 깔때기에 넣고 $n$-hexane 층과 distilled water 층을 분획하였고, distilled water 층을 다시 chloroform과 1:1 비율로 분액 깔때기에 넣고 chloroform과 distilled water 층을 분획하였다. 이 과정과 동일하게 ethyl acetate, butanol 을 distilled water 층과 분획을 실시한 후 농축하여 동결건조(IIShin Lab Co., Ltd., Yangju, Korea)하였고, 그 후 $-20^{\circ} \mathrm{C}$ 에서 보관하면 서 각 실험에 사용하였다. $n$-hexane, chloroform, ethyl acetate, butanol 및 distilled water 분획물의 추출 수율(extraction yield)은 각각 $3.81,1.46,0.45,2.36$ 및 $5.79 \%$ 로 나타났다.

\section{Total phenolic 화합물 함량}

추출 시료 용액 $1 \mathrm{~mL}$ 에 3 차 distilled water $9 \mathrm{~mL}$ 를 혼합한 후 Folin-Ciocalteau's phenol reagent $1 \mathrm{~mL}$ 를 넣고 혼합하여 실온에서 5 분간 반응시켰다. 반응용액에 $7 \% \mathrm{Na}_{2} \mathrm{CO}_{3}$ 용액 $10 \mathrm{~mL}$ 를 넣어 다 시 혼합한 다음 3 차 distilled water를 $25 \mathrm{~mL}$ 로 정용하였다. 이 혼 합 용액을 $23^{\circ} \mathrm{C}$ 에서 2 시간 동안 반응시킨 후 $760 \mathrm{~nm}$ 에서 흡광도 (Libra S32PC, Biochrom Ltd., Cambridge, UK)를 측정하였다. 측 정된 흡광도는 gallic acid 검량선을 이용하여 총 페놀화합물 함 량을 계산하였다(14).

\section{ABTS radical 소거활성 및 지질 과산화물(MDA) 생성 억제효과}

$1.0 \mathrm{mM}$ AAPH (2,2'-azobis-(2-amidinopropane) $\mathrm{HCl})$ 와 $2.5 \mathrm{mM}$ $\mathrm{ABTS}$ 를 $150 \mathrm{mM} \mathrm{NaCl}$ 이 더해진 $100 \mathrm{mM}$ phosphate buffer $(\mathrm{pH}$ 7.4)와 함께 혼합하여 $68^{\circ} \mathrm{C}$ water bath에서 30 분 동안 열을 가하 고 실온에서 10 분 동안 냉각하였다. ABTS radical 용액은 $734 \mathrm{~nm}$ 에서 흡광도 값이 $0.65 \pm 0.02$ 이 나오도록 buffer로 희석시켜 사용 하였다. 시료용액 $20 \mu \mathrm{L}$ 에 흡광도 값을 조정한 $\mathrm{ABTS}$ 용액 980 $\mu \mathrm{L}$ 를 혼합하여 $37^{\circ} \mathrm{C}$ 에서 10 분간 반응시키고, $734 \mathrm{~nm}$ 에서 흡광도 를 측정하였다(15).

뇌 조직을 이용한 지질 과산화 억제활성 측정은 Chang 등(16) 의 방법을 변형하여 사용하였다. 4주령의 ICR-male mouse를 실 험동물 공급업체(Samtako, Osan, Korea)로부터 구입하여 7일간의 환경 적응 기간을 유지했다. 모든 실험동물은 2 마리씩 한 개의 사육케이스에 넣어 항온 $\left(22 \pm 2^{\circ} \mathrm{C}\right)$, 항습 $(50-55 \%)$ 을 일정하게 유지 하였고, 12 시간 간격으로 낮과 밤을 교대시키는 동일한 환경에서 충분한 양의 식수와 사료를 공급하며 사육하였다(경상대학교 동 물실험인가번호 GNU-120831-M0037). 상기환경에서 4주간 사육 한 ICR mouse brain을 적출하여 실험에 사용하였다. 뇌 조직에 10 volume의 ice cold Tris- $\mathrm{HCl}$ buffer $(20 \mathrm{mM}, \mathrm{pH}$ 7.4)에 균질 화시켜 원심분리 하였다. 상등액 $0.1 \mathrm{~mL}$ 에 $10 \mu \mathrm{M} \mathrm{FeSO} \mathrm{F}_{4} 0.1 \mathrm{~mL}$, $0.1 \mathrm{mM}$ ascorbic acid $0.1 \mathrm{~mL}$ 및 시료 $0.2 \mathrm{~mL}$ 를 혼합하여 $37^{\circ} \mathrm{C}$ 에 서 1 시간 동안 배양하였다. 그후 $30 \%$ trichloroaceticacid $0.1 \mathrm{~mL}$ 와 $1 \%$ thiobarbituric acid $0.3 \mathrm{~mL}$ 를 첨가하여 $80^{\circ} \mathrm{C}$ 에서 20 분간 가 열한 후, $532 \mathrm{~nm}$ 에서 흡광도를 측정하였다.

\section{신경세포 배양 및 세포 내 산화적 스트레스 생성 억제효과}

본 실험에서 사용한 PC12 cell (KCLB 21721, Korean Cell Line Bank, Seoul, Korea)는 신경세포의 특성을 나타내는 세포로 rat의 pheochromocytoma에서 유도된 것을 사용하였다. PC12세포 를 $25 \mathrm{mM}$ HEPES, $25 \mathrm{mM}$ sodium bicarbonate, $10 \%$ fetal bovine serum, 50 units $/ \mathrm{mL}$ penicillin 및 $100 \mu \mathrm{g} / \mathrm{mL}$ steptomycin이 포함된 RPMI 1640 배지에 접종하여 $37^{\circ} \mathrm{C}, 5 \% \mathrm{CO}_{2}$ 조건에서 배양하였다.

$\mathrm{PC} 12$ 세포 내 산화적 스트레스 생성량 측정을 위하여 DCF$\mathrm{DA}$ assay를 이용하였다. 산화적 스트레스로 인해 세포 내 생성 된 ROS는 비형광성을 나타내는 DCF-DA (2'7'-dichlorodihydrofluorescein diacetate)를 산화시켜 형광물질인 $\mathrm{DCF}$ 로 전환시키는데 이렇게 전환된 형광물질의 양을 측정하여 세포 내 형성된 ROS 를 측정하는 방법이다. 실험 방법은 세포 $10^{5}-10^{6} \mathrm{cell} / \mathrm{mL}$ 에 시료 $20 \mu \mathrm{L}$ 를 48시간 동안 pre-incubation 하였다. 후에, $200 \mu \mathrm{M} \mathrm{H} \mathrm{H}_{2} \mathrm{O}_{2}$ 를 2시간 동안 처리하였고, 다음 $250 \mu \mathrm{M} \mathrm{DCF-DA를} \mathrm{넣어} 50$ 분 간 배양하여 fluorescence microplate reader (Infinite 200, Tecan Co., San Jose, CA, USA)를 사용하여 $485 \mathrm{~nm}$ (determination)와 $535 \mathrm{~nm}$ (reference)에서 fluorescence level을 측정하였다(17). 


\section{신경세포 생존율 및 세포막 손상 억제효과}

PC12 세포에 대한 보호효과는 MTT assay kit를 이용하였다. MTT reduction assay는 mitochondrial dehydrogenase에 의해 노란 색의 수용성 기질을 청자색을 띠는 비수용성의 MTT formazan으 로 환원시키는 mitochodrial activity를 이용하는 측정방법이다(18). 실험 방법은 시료 $30 \mu \mathrm{L}$ 를 $\mathrm{PC} 12$ 세포에 48시간 동안 pre-incubation한 뒤, $200 \mu \mathrm{M} \mathrm{H}_{2} \mathrm{O}_{2}$ 를 3 시간 동안 처리하였다. 이 상태의 PC12 세포에 MTT stock solution $\left(10 \mu \mathrm{L} /\right.$ well) 을 처리하여 $37^{\circ} \mathrm{C}$ 에서 3시간 incubation 시킨 후, $\mathrm{DMSO} 100 \mu \mathrm{L}$ 를 첨가하여 반응 을 종결시켰다. 최종 흡광도는 microplate reader (model 680, Bio$\mathrm{rad}$, Tokyo, Japan)에서 $570 \mathrm{~nm}$ (determination)와 $690 \mathrm{~nm}$ (reference wave)에서 측정하였다. Positive control은 vitamin C (200 $\mu \mathrm{M}$ )를 사용하였고, 세포 생존율은 control에 대한 \% unit으로 나 타냈다(19).

시료의 세포막 손상 억제효과는 $\mathrm{PC} 12$ 세포에 시료를 48시간 동안 pre-incubation한 후, $200 \mu \mathrm{M} \mathrm{H}_{2} \mathrm{O}_{2}$ 를 처리하여 3시간 배양한 다음, 5 분간 원심분리 $(250 \times g)$ 하여 $100 \mu \mathrm{L}$ 의 상등액을 새로운 well 로 옮긴 뒤 LDH assay kit (Sigma-Aldrich Chemical Co.)를 이용 하여 측정하였다(19).

\section{$\mathrm{HPLC}$ analysis를 통한 생리활성물질 분석}

위 실험에서 나타난 생리활성물질을 동정하기 위해 HPLC (Ultra mate 3000 series, Dionex, CA, USA) 분석을 실시하였으며, $\mathrm{HPLC}$ 분석 전에 $0.45 \mu \mathrm{m}$ filter를 이용하여 여과하였다. 분석조건 중 column은 $\mathrm{C}_{18}$ column $(250 \times 4.6 \mathrm{~mm}, 5.0 \mu \mathrm{m}$, ProtoSIL, BISCHOFF Chromatography, Leonberg, Germany)을 사용하였고, 이동 상은 $0.01 \mathrm{M}$ potassium phosphate buffer ( $\mathrm{pH}$ 3.0) (A)와 methanol (B)의 조성비를 $10-32 \%$ (0-9.5 min), 32-33\% (9.5-13 min), $33-80 \%$ (13-30 $\mathrm{min}), 80-10 \%$ (30-31 $\mathrm{min}), 10 \%$ (31-36 min)으로 총 36 분간 분석하였다. 시료의 주입량은 $20 \mu \mathrm{L}$, 이동상 유속은 $1.5 \mathrm{~mL} / \mathrm{min}$ 이며, $\mathrm{UV}$ 검출장치의 파장은 diode array detector (DAD)로 $280 \mathrm{~nm}$ 에서 분석하였다.

\section{통계처리}

모든 실험은 3 회 반복 실시하여 mean $\pm \mathrm{SD}$ 로 나타냈으며, 각 평 균값에 대한 검증은 SAS software (version 9.1, SAS institute, Cary, NC, USA)을 이용하여 분산분석(analysis of variance, ANOVA)를 실시하고, Ducan의 다중범위검정법(Duncan's multiple range test)으로 각 시료간의 유의차를 $5 \%$ 수준에서 검증하였다.

\section{결과 및 고찰}

\section{Total phenolic 화합물 함량}

고등식물에서 발견되는 천연 항산화 물질 중 가장 많은 부분을 차지하는 것이 phenolic 화합물이다. Inorganic phenol은 독성이 강 한 물질이나 페놀분자의 환상구조에 치환기로서 수산기 $(-\mathrm{OH})$ 가 더 해짐에 따라 일반적으로 독성이 저하되고 항산화 활성 및 라디 칼 소거 활성 등이 증가하게 된다고 알려져 있다(10). 최적의 추 출용매를 결정하기 위해 $95 \%$ ethanol을 이용하여 조 추출물을 제 조한 뒤 $n$-hexane, chloroform, ethyl acetate, butanol, distilled water 순으로 분획물을 얻어 total phenolics를 분석하였다. 분석결 과 $95 \%$ ethanol 추출물이 $51.75 \mathrm{mg}$ GAE (Gallic Acid Equivalents)/g of dried broccoli leaf, $n$-hexane 분획물이 $48.7 \mathrm{mg} \mathrm{GAE} / \mathrm{g}$ of dried broccoli leaf, chloroform 분획물이 $206.8 \mathrm{mg} \mathrm{GAE} / \mathrm{g}$ of dried broccoli leaf, ethyl acetate 분획물이 $175.5 \mathrm{mg} \mathrm{GAE} / \mathrm{g}$ of

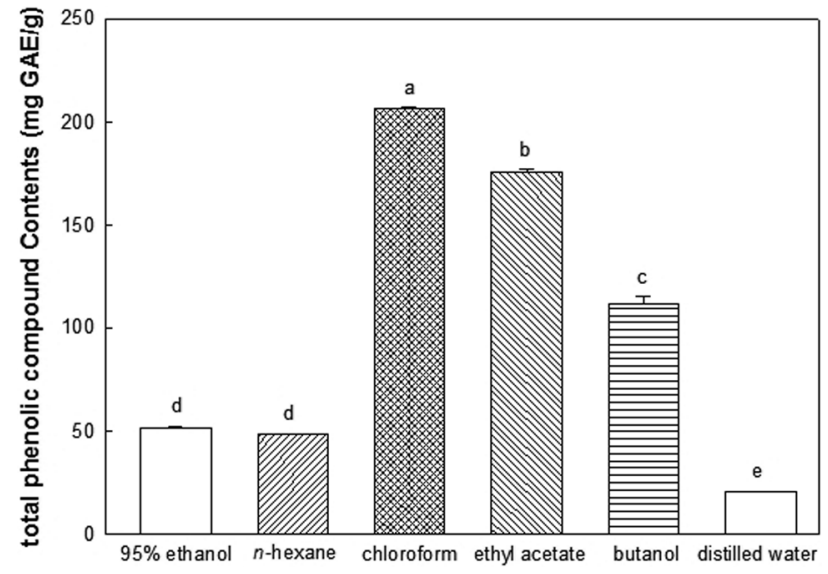

Fig. 1. Total phenolic compound contents of $n$-hexane, chloroform, ethyl acetate, butanol and distilled water fractions from $95 \%$ ethanol extract of broccoli leaves. Results shown are means \pm SD $(n=3)$. Data were statistically considered at $p<0.05$ and different small letters represent statistical differences.

dried broccoli leaf, butanol $111.8 \mathrm{mg} \mathrm{GAE} / \mathrm{g}$ of dried broccoli leaf, distilled water $20.5 \mathrm{mg} \mathrm{GAE} / \mathrm{g}$ of dried broccoli leaf으로 chloroform 분획물에서 가장 높은 total phenolic 화합물 함량을 나 타내었다(Fig. 1). 이는 분획 전(95\% ethanol 추출물)과 후를 비교 했을 때, chloroform 분획물에서 약 4 배의 total phenolic 화합물 함량이 증가하였다.

Bidchol 등(5)은 브로콜리 ethanol 추출물의 total phenolic 화합 물 함량은 $13.96 \mathrm{mg}$ guaiacol $/ \mathrm{g}$ 으로, 높게 나타나는 항산화 실험 결과와 비교했을 때 다소 낮은 total phenolic 화합물 함량을 나 타내었는데, 이는 non-phenolic 화합물에 의한 결과라고 보고하였 다. 이는 본 실험에서 $95 \%$ ethanol 추출물에서는 낮은 total phenolic 화합물 함량을 나타내었지만, 분획과정을 통하여 많은 nonphenolic 화합물들은 $n$-hexane, distilled water 용매로 분획되어 졌 고, phenolic 화합물은 chloroform, ethyl acetate 용매로 분획되어 total phenolic 화합물에 차이가 나타난 것으로 판단된다.

ABTS radical 소거활성 및 지질 과산화물(MDA) 생성 억제효과

ABTS assay는 수용성 및 지용성 물질의 항산화 측정에 모두 적용할 수 있기 때문에 식품의 항산화 활성을 측정하는데 널리 사용되고 있으며, ABTS radical이 시료의 항산화 물질에 의해 제 거되면 특유의 색인 청록색이 탈색되는 점을 이용한 측정 방법 이다(22,23). Positive control로 사용된 vitamin $\mathrm{C}$ 는 활성산소의 포 착제로 hydroxyl radical (HO)와 반응하여 명확하게 소거하며 그 효과는 강한 환원성에 의한 항산화 작용에 기인한 것으로 positive control로 많이 사용된다(10). 5가지 분획물을 이용하여 ABTS radical 소거활성을 측정한 결과는 Fig. 2(A)와 같다. 모든 분획물 은 농도 의존적인 경향을 나타내었으며, 그 중 chloroform 분획 물에서 상대적으로 가장 높은 활성을 나타내었다. 특히 브로콜리 잎 chloroform분획물 $1,000 \mu \mathrm{g} / \mathrm{mL}$ 농도에서는 positive control인 vitamin C $1,000 \mu \mathrm{g} / \mathrm{mL}$ 농도와 유의적으로 차이가 나타나지 않는 것을 보아 우수한 $\mathrm{ABTS}$ radical 소거활성을 나타내는 것을 알 수 있었다.

$\mathrm{ROS}$ 와 같은 산화적 스트레스에 대한 브로콜리 잎 chloroform 분획물의 지질 과산화물(malondialdehyde, $\mathrm{MDA}$ ) 생성 억제효과 를 분석하여 in vitro 항산화 활성을 확인하였다. 신경세포막을 구 

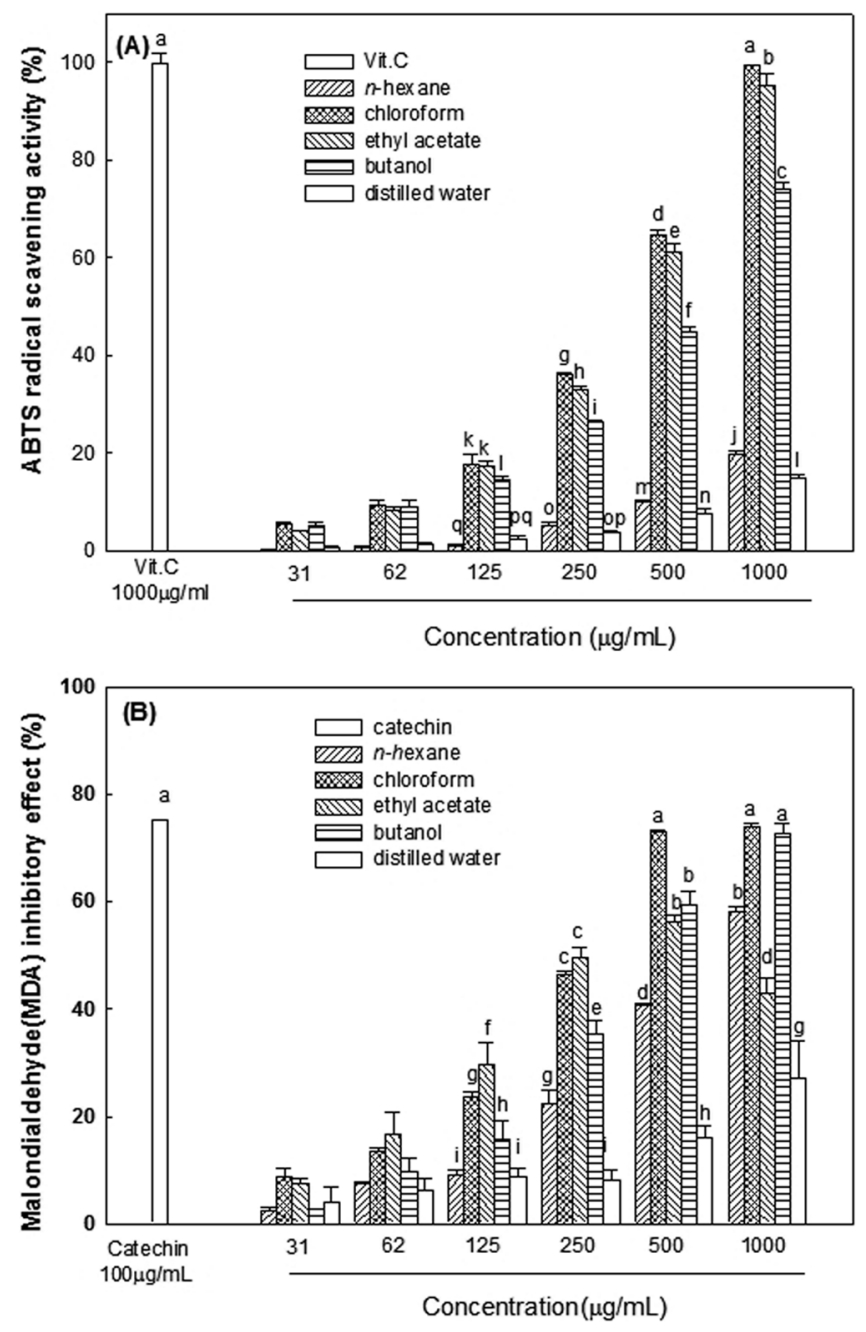

Fig. 2. ABTS radical scavenging activities (A) and malondialdehyde (MDA) production inhibitory effect of various fractions from broccoli leaves. Results shown are mean \pm SD $(n=3)$. Data were statistically considered at $p<0.05$, and different small letters represent statistical differences.

성하고 있는 지질성분은 산화적 스트레스에 취약한 특성을 가지 고 있으며, 세포막 손상 및 기타 단백질 손상과도 관계가 있다고 알려져 있다(22). 따라서 본 연구에서는 마우스 뇌 세포막 지질 과산화 중간생성물인 $\mathrm{MDA}$ 생성 억제효과를 살펴보았다(Fig. 2(B)). ABTS radical 소거활성과 유사하게 모든 분획물에서 농도 의존적인 경향을 나타내었으며, 5 가지 분획물 중에서 chloroform 분획물과 butanol 분획물에서 높은 활성을 보였다. 하지만 positive control로 사용된 catechin과 비교하였을 때 chloroform 분획물 500 $\mu \mathrm{g} / \mathrm{mL}$ 의 농도에서 보다 우수한 $\mathrm{MDA}$ 저해효과을 보였다.

Bidchol 등(5)의 ethanol에 침지추출한 브로콜리의 지질 과산화 물 생성 억제효과에 대한 $\mathrm{IC}_{50}$ 값은 $0.44 \mathrm{mg} / \mathrm{mL}$ 로 나타났으며, 브 로콜리 꽃봉오리 추출물이 지질 막의 손상을 억제함으로써 지질 막 이중 층의 double bond로부터 수소원자의 방출을 억제하는 hydroxyl groups를 가지고 있는 특정 biomolecule들에서 기인된 것 이라고 보고하였다. 그러므로 브로콜리 잎 chloroform 분획물의 phenolic 화합물들의 구조에 hydroxyl group을 내포하는 biomolecule들에 의하여 쥐의 뇌조직이 과산화 되는 것을 억제되는 것으 로 판단된다.

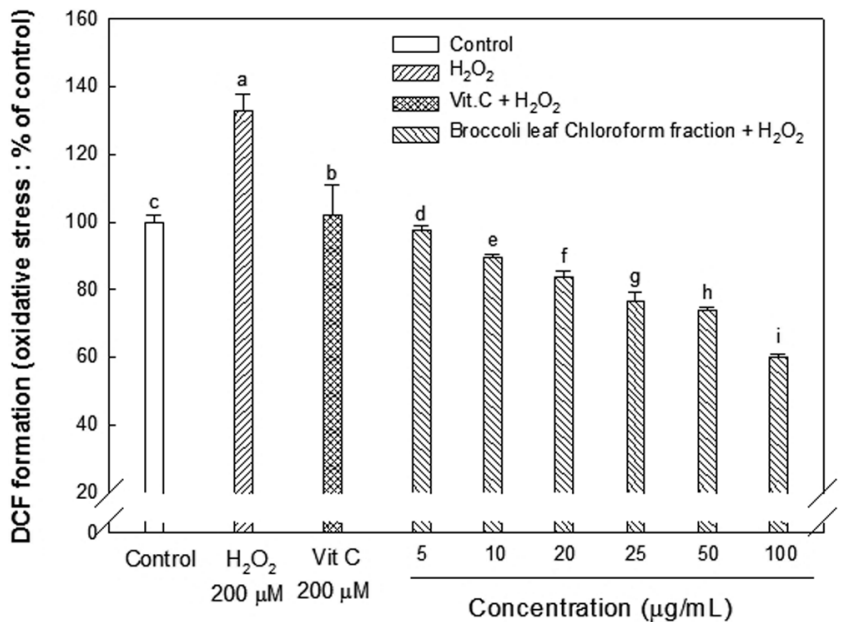

Fig. 3. Effect of chloroform fraction from broccoli leaves on ROS production in presence and absence of $\mathrm{H}_{2} \mathrm{O}_{2}$ in $\mathrm{PC12}$ cells. Results shown are mean \pm SD $(n=3)$. Data were statistically considered at $p<0.05$, and different small letters represent statistical differences.

\section{세포 내 산화적 스트레스 생성 억제효과}

퇴행성 신경질환은 대부분 산화적 스트레스에 의한 뇌신경세 포의 사멸에 의해 발생되며, natural antioxidant인 flavonoid를 포 함한 polyphenols 등은 산화적 스트레스로부터 신경세포 보호 효 과가 우수한 것으로 보고되고 있다(24). 상기의 in vitro 항산화 활성을 통해 우수한 활성을 보여준 chloroform 분획물을 이용하 여 실험을 진행하였다. Chloroform 분획물에 의한 PC12 신경세 포에서의 $\mathrm{H}_{2} \mathrm{O}_{2}$ 로 유도된 산화적 스트레스 생성 억제 효과를 DCF$\mathrm{DA}$ assay로 측정한 결과는 Fig. 3 와 같다 $\mathrm{H}_{2} \mathrm{O}_{2}$ 를 단독 처리한 군 에서는 $132 \%$ 로 control group에 대비하여 약 $32 \%$ 의 형광 강도 증가(pattern of oxidative stress)를 보인 반면, chloroform 분획물 을 처리한 구에서는 농도 의존적으로 산화적 손상에 대한 신경 세포(PC12 cell) 보호 효과를 보였다. 특히 농도 $100 \mu \mathrm{g} / \mathrm{mL}$ 에서 는 약 $60 \%$ 로 $\mathrm{H}_{2} \mathrm{O}_{2}$ 대비 약 $73 \%$ 정도의 $\mathrm{ROS}$ 감소율을 보여주 어 뛰어난 신경세포 내 산화적 스트레스 생성 억제효과를 나타 내는 것으로 확인되었다. Hurst 등(25)에 의하면 phenolic 화합물 은 산화적 스트레스에 의한 세포 손상을 보호할 수 있다고 보고 하였으며, 이에 따라 본 연구에서도 브로콜리 잎 chloroform 분 획물에 존재하는 phenolic 화합물들에 의해 산화적 스트레스 생 성 억제 효과가 나타났을 것으로 판단된다.

\section{신경세포 생존율 및 세포막 손상 억제효과}

Chloroform 분획물의 $\mathrm{H}_{2} \mathrm{O}_{2}$ 로 유도된 산화적 스트레스 상태에 서 $\mathrm{PC} 12$ 신경세포의 생존율을 MTT assay로 측정한 결과는 Fig. $4(\mathrm{~A})$ 와 같다. $\mathrm{H}_{2} \mathrm{O}_{2}$ 를 처리한 처리구에서는 control group 대비 $77 \%$ 의 cell viability를 나타냈고, $\mathrm{H}_{2} \mathrm{O}_{2}$ 와 vitamin $\mathrm{C}$ 를 동시에 처 리한 group에서는 $106 \%$ 로 약 $29 \%$ 의 신경세포 생존율을 보였다. Chloroform 분획물을 처리한 group에서는 $5-10 \mu \mathrm{g} / \mathrm{mL}$ 농도에서 positive control group과 대비하여 유의적인 생존율을 나타내었으 며, $20 \mu \mathrm{g} / \mathrm{mL}$ 농도 이상에서는 $200 \mu \mathrm{M}$ vitamin $\mathrm{C}$ 와 유사한 신경 세포 생존율을 나타내었고, 그 이상의 처리구에서는 농도 의존적 으로 생존율이 증가하는 것을 확인 할 수 있었다. Kim 등(26)의

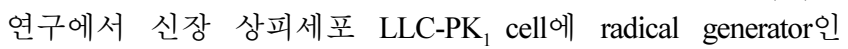
$\mathrm{AAPH}$ 로 산화적 스트레스를 유도한 결과 브로콜리 꽃 봉오리, 줄 기 부위의 chloroform 분획물 농도 $50 \mu \mathrm{g} / \mathrm{mL}$ 에서 각각 $64.6 \%$, 

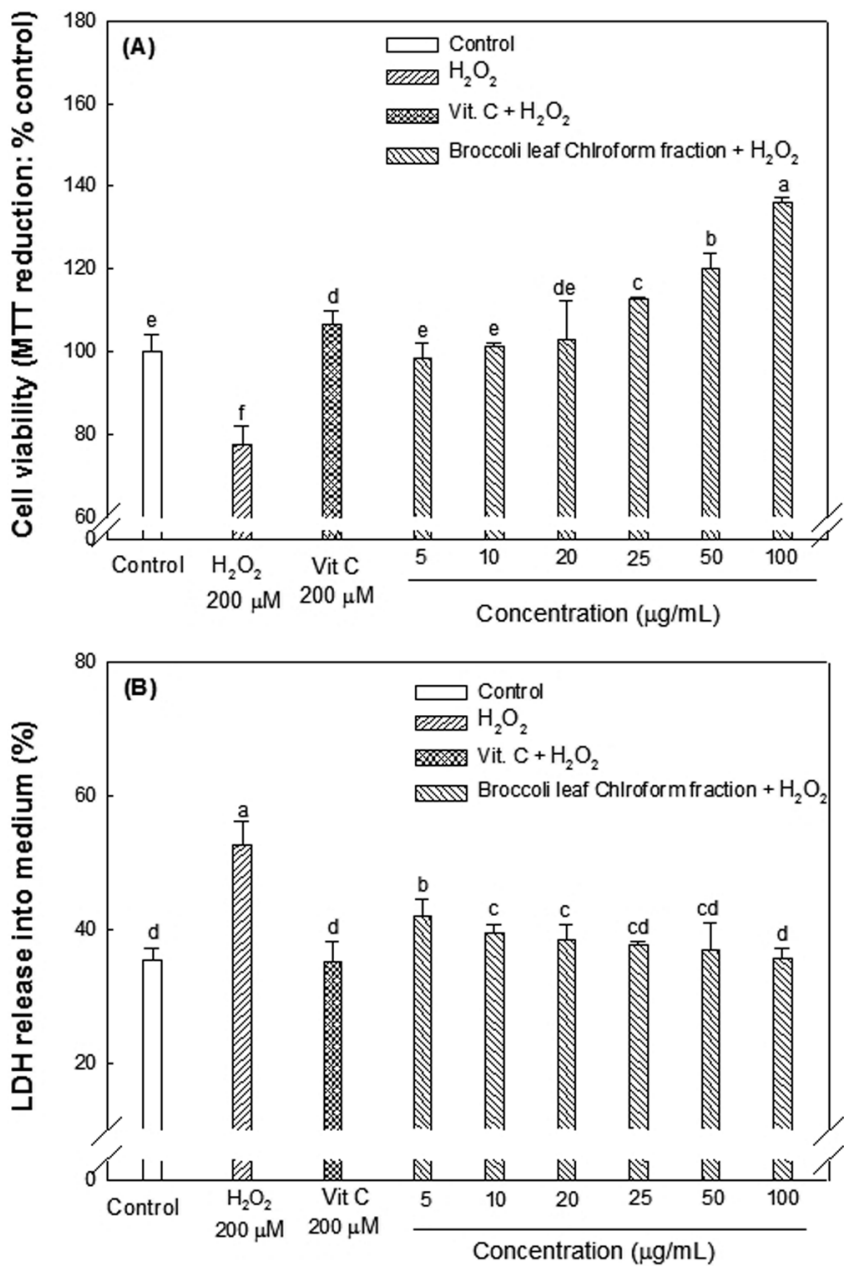

Fig. 4. Neuronal cell-protective effect of chloroform fraction from broccoli leaves on $\mathrm{H}_{2} \mathrm{O}_{2}$-induced cytotoxicity in $\mathrm{PC12}$ cells (A) and $\mathrm{LDH}$ release inhibitory effect of chloroform fraction from broccoli leaves on $\mathrm{H}_{2} \mathrm{O}_{2}$-induced membrane damage in PC12 cells (B). Results shown are mean \pm SD $(n=3)$. Data were statistically considered at $p<0.05$, and different small letters represent statistical differences.

$76.7 \%$ 의 세포 생존율을 보였다. 본 연구 결과와 비교 해 볼 때, 브로콜리의 부위별 세포생존율은 꽃 봉오리, 줄기 부위보다 잎 부위에서 상대적으로 더 좋은 세포 생존율을 가지는 것을 유추 해 볼 수 있었다.

신경세포의 경우 전기적 신호전달이라는 고유 기능유지를 위 해 상대적으로 많은 lipid성분을 함유하고 있고 이는 산화적인 스 트레스에 매우 취약한 구조적 특성이므로(27) $\mathrm{H}_{2} \mathrm{O}_{2}$ 로 유도된 신 경세포막 손상에 대한 브로콜리 잎 chloroform 분획물의 보호 효 과를 확인하였다. $\mathrm{H}_{2} \mathrm{O}_{2}$ 로 유도된 신경세포막 손상에 대한 브로 콜리 잎 chloroform 분획물의 세포막 손상 억제효과를 확인하기 위해 세포질 성분인 $\mathrm{LDH}$ assay를 수행한 결과는 Fig. 4(B)와 같 다. Control group의 LDH 방출량은 $35 \%$ 정도인데 반해 $\mathrm{H}_{2} \mathrm{O}_{2}$ 처 리한 시료에서는 $52 \%$ 의 방출량을 보여 $\mathrm{H}_{2} \mathrm{O}_{2}$ 에 의해 $\mathrm{LDH}$ 방출 량이 약 $17 \%$ 정도 증가하였다. Positive control로 쓰인 vitamin C $200 \mu \mathrm{M}$ 처리군은 $35 \%$ 정도의 $\mathrm{LDH}$ 방출량을 보였고, 브로콜리 잎 chloroform 분획물의 경우 $5-100 \mu \mathrm{g} / \mathrm{mL}$ 의 농도로 처리했을 때 농도 의존적인 감소 효과를 보였으며, $100 \mu \mathrm{g} / \mathrm{mL}$ 농도 처리구에 서는 positive control인 vitamin C $200 \mu \mathrm{M}$ 처리구와 유사한 세포

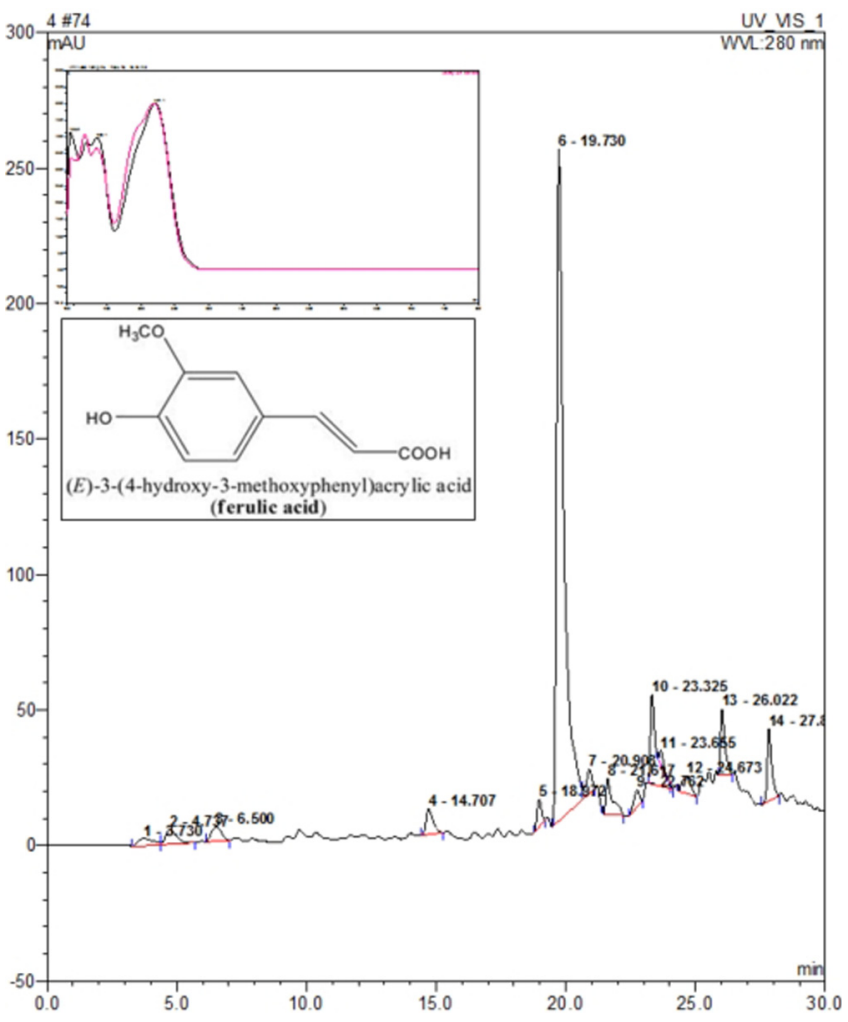

Fig. 5. HPLC chromatograms of chloroform fraction from broccoli leaves at $280 \mathrm{~nm}$. Phenolic compounds were identified by comparing their retention time (RT) values to UV spectra of known standards. All analyses were run in triplicate, and RT of ferulic acid was $19.730 \mathrm{~min}$.

막 손상 억제 효과를 나타내었다.

\section{HPLC analysis를 통한 생리활성물질 분석}

In vitro 항산화 활성과 신경세포 보호 효과를 유도하는 주요 생리활성물질로서의 phenolic 화합물 분석을 위한 HPLC analysis 결과는 Fig. 5와 같다. HPLC 분석결과, $19.730 \mathrm{~min}$ 에서 확인된 peak는 브로콜리 잎 chloroform 분획물의 주요한 생리활성물질임 을 확인하였고, 이는 표준물질 ferulic acid의 retention time과 UVVIS spectrum을 비교 하였을 때 일치 하는 것으로 확인되었다.

Ferulic acid (4-hydroxy-3-methoxycinnamic acid)는 식물에 풍부 하게 존재하는 물질로써, 암, 심혈관계질환, 당뇨, 알츠하이머병 등에 효과가 있는 항산화제로 알려져 있다(28). 또한 Kanski 등 (29)에 의하면 ferulic acid는 lipid oxidation의 산화적 수준의 감소 효과, $\mathrm{AAPH}$ 에 의해 산화적 스트레스를 유도한 hippocampal neuronal cells에서 신경세포 보호 효과 및 세포 내 ROS 생성 저해 효과 등이 있음을 보고하였다. 이러한 보고들에 의하여 판단해 보았을 때, 브로콜리 잎 chloroform 분획물에서 확인된 주요 phenolic 화합물로써 ferulic acid 등에 의한 in vitro 항산화 활성 과 신경세포 보호 효과를 나타낸 것으로 추정된다. 하지만 미량 존재 할 수 있는 다양한 phytochemical에 의한 부가적인 효과를 배제할 수 없으므로 향후 관련 생리활성 성분 분석 및 in vivo 실험들에서의 추가적인 검증이 필요할 것으로 판단된다.

\section{요 약}

브로콜리(Brassica oleracea var. italica) 잎의 $n$-hexane, chloro- 
form, ethyl acetate, butanol 및 distilled water 분획물의 total phenolic 화합물 함량은 chloroform 분획물이 $206.8 \mathrm{mg} \mathrm{GAE} / \mathrm{g}$ 으로 가 장 높게 나타났으며, $\mathrm{ABTS}$ radical 소거활성 및 지질 과산화 (MDA) 생성 억제효과 실험 결과에서 chloroform 분획물에서 가 장 높은 활성을 나타내었다. in vitro 항산화 실험들에서 우수한 효과를 보인 chloroform 분획물을 이용하여 $\mathrm{H}_{2} \mathrm{O}_{2}$ 으로 유도한 산 화적 스트레스에 대한 신경세포(PC12 cell)에서의 산화적 스트레 스 생성 억제효과, 세포 생존율 그리고 세포막 손상 억제효과 역 시 농도 의존적 경향을 나타내며 positive control 로 사용된 Vit.C 와 유의적인 결과를 나타냈다. 마지막으로, HPLC 분석 결과 브 로콜리 잎 chloroform 분획물에 존재하는 주요 phenolic 화합물은 feulic acid인 것으로 확인되었다. 본 연구 결과를 종합해볼 때, 생 리활성 물질로서의 ferulic acid 등을 함유한 브로콜리 잎 chloroform 분획물은 in vitro 항산화 활성과 함께 신경세포 보호효과를 나타내는 고부가가치 기능성 소재로의 활용이 기대된다.

\section{감사의 글}

본 연구는 한국연구재단에 의해 지원된 연구(KRF-2011-0021664) 및 2013년 산림청 산림과학기술개발사업(2013-자유10)의 지원을 받아 수행된 결과의 일부로 이에 감사 드립니다. 또한 박선경, 진 동은, 박창현 그리고 승태완은 교육부 BK21 plus program의 지 원을 받아 연구를 수행하였고 이에 감사 드립니다.

\section{References}

1. Park SH, Hwang HS, Han JH. Development of drink from composition with medicinal plants and evaluation of its physiological function. Korean J. Nutr. 37: 364-372 (2004)

2. Jeong EJ, Kim JW, Kim YC. Rhus verniciflua stokes attenuates glutamate-induced neurotoxicity in primary cultures of rat cortical cells. Nat. Prod. Sci. 14: 156-160 (2008)

3. Fridovich, I. Biological effects of the superoxide radical. Arch. Biochem. Biophys. 247: 1-11 (1986)

4. Heo HJ, Kim DO, Choi SJ, Shin DH and Lee CY. Potent inhibitory effect of flavonoids in Scutellaria baicalensis on amyloid â protein-induced neurotoxicity. J. Agr. Food Chem. 52: 4128-4132 (2004)

5. Bidchol AM, Wilfred A, Abhijna $P$ and Harish R. Free radical scavenging activity of aqueous and ethanolic extract of Brassica oleracea L. var italic. Food Bioprocess Technol. 4: 1137-1143 (2011)

6. Nohl H and Jordan, W. The mitochondrial site of superoxide formation. Biochem. Biophy. Res. Commun. 138: 533-539 (1986)

7. Yoon MY, Lee BB, Kim JY, Kim YS, Park EJ, Lee SC, Park HR. Antioxidant activity and neuroprotective effect of psoralea corylifolia linne extracts. Korean J. Pharmacol. 38: 84-89 (2007)

8. Matucsheski NV, Juvik JA, Jeffery EH. Heating decreases epithiospecifier protein activity and increases sulforaphane formation in broccoli. Phytochemistry 65: 1273-1281 (2004)

9. Caudhary A, Sharma U, Vig AP, Singh B, Arora S. Free radical scavenging, antiproliferative activities and profiling of variations in the level of phytochemicals in different parts of broccoli (Brassica oleracea italica). Food Chem. 148: 373-380 (2014)

10. Lee HS, Park YW. Antioxidant activity and antibacterial activities from different parts of broccoli extracts under high temperature. J. Korean Soc. Food Sci. Nutr. 34: 759-764 (2005)
11. Kim $\mathrm{CH}$, Cho KR. Quality characteristics of sponge cakes made with different quantities of broccoli powder. Korean J. Food Sci. Technol. 42: 459-467 (2010)

12. Stoewsand G.S. Bioactive organosulfur phytochemicals in Brassica oleracea vegetables-a review, Food Chem. Toxicol. 33: 537 (1995)

13. Arnáiz E, Bernal J, Martín MT, Nozal MJ, Bernal JL, Toribio L. Supercritical fluid extraction of free amino acids from broccoli leaves. J. Chromatogr. A 1250: 49-53 (2012)

14. Kim, DO, Jeong SW, Lee CY. Antioxidant capacity of phenolic phytochemical from various cultivars of plums. Food Chem. 81: 321-326 (2003)

15. Kwak JH, Choi GN, Pack JH, Kim JH, Jeong HR, Jeong CH, Heo HJ. Antioxidant and neuronal cell protective effect of purple sweet potato extract. J. Agric. Life Sci. 44: 57-66 (2010)

16. Chang ST, Wu JH, Wang SY, Kang PL, Yang NS, Shyur, LF. Antioxidant Activity of Extracts from Acacia confusa Bark and Heartwood. J. Agr. Food Chem. 49: 3420-3424 (2001)

17. Kim JK, Choi SJ, Cho HY, Hwang HJ, Kim YJ, Lim T, Kim CJ, Kim HK, Peterson S, Shin DH. Protective effects of kamepferol(3,4',5,7-tetrahydroxyflavone) against amyloid beta peptide(A $\beta$ )-induced neurotoxicity in ICR mice. Biosci. Biotechnol. Biochem. 74: 397-401 (2010)

18. Kim SS, Park RY, Jeon HJ, Kwon YS, Chun W. Neuroprotective effects of 3,5-dicaffeoylquinic acid on hydrogen peroxide-induced cell death in SH-SY5Y cells. Phytother. Res. 19: 243-245 (2005)

19. Heo HJ, Cho HY, Hong BS, Kim HK, Kim EK, Kim BK, Shin DH. Protective effect of 4',5-dihydroxy-3',6,7-trimethoxyflavone from Artemisia asiatica against $\mathrm{A} \beta$-induced oxidative stress on PC12 cells. Amyloid 8: 194-201 (2001)

20. Kim KH, Kim HJ, Byun MW, Yook HS. Antioxidnat and antimicrobial activities of ethanol extract from six vegetables containing different sulfur compounds. J. Korean Soc. Food Sci. Nutr. 41: 577-583 (2012)

21. Yoo KM, Kim DO, Lee CY. Evaluation of different methods of antioxidant measurement. Food Sci. Biotechnol. 16: 177-182 (2007)

22. Re R, Plellegrini N, Proteggente A, Pannala A, Yang M, RiceEvans C. Antioxidant activity applying an improved ABTS radical cation decolorization assay. Free Radical Bio. Med. 26: 12311237 (1999)

23. Uchida K, Stadtman ER. Covalent attachment of 4-hydroxynonenal to glyceraldehyde-3-phosphate dehydrogenase A possible involvement of intra and intermolecular cross-linking reaction. J. Biol. Chem. 268: 6388-6393 (1993)

24. Zhao B. Natural antioxidants protect neurons in Alzheimer's disease and Parkinson's disease. Neurochem. Res. 34: 630-638 (2009)

25. Hurst RD, Wells RW, Hurst SM, McGhie TK, Cooney JM, Jensen DJ. Blueberry fruit polyphenolics suppress oxidative stress-induced skeletal muscle cell damage in vitro. Mol. Nutr. Food Res. 54: 353-363 (2010)

26. Kim HY, Lee YA, Cho EJ. Free radical scavenging effect and protective activity from oxidative stress of broccoli flowers and sprouts. CNU J. Agric. Sci. 39: 81-86 (2012)

27. Heo HJ, Choi SJ, Choi SG, Shin DH, Lee JM, Lee CY. Effect of banana, orange, and apple on oxidative stress-induced neurotoxicity in PC12cells. J. Food Sci. 73: H28-32 (2008)

28. Zhao Z, Moghadasian MH. Chemistry, natural sources, dietary intake and pharmacokinetic properties of ferulic acid: A review. Food Chem. 109: 691-702 (2008)

29. Kanski J, Aksenova M, Stoyanova A, Butterfield A. Ferulic acid antioxidant protection against hydroxyl and peroxyl radical oxidation in snaptosomal and neuroal cell culture systems in vitro: structure-activity studies. J. Nutr. Biochem. 13: 273-281 (2002) 